Journal of Educational Technology

\& Online Learning

Volume 2 | Issue 2 | 2019

http://dergipark.gov.tr/jetol

\title{
Book Review: Handbook of Research on Learning in the Age of Transhumanism
}

Şeyda KIR ${ }^{\mathrm{a}}$

${ }^{a}$ seydaakr@gmail.com; Anadolu University, Eskişehir, Turkey; ORCID: 0000-0002-6270-8034

Doi: $10.31681 /$ jetol.559414

Suggested Citation: Kır, Ş. (2019). Book Review: Handbook of Research on Learning in the Age of Transhumanism. Journal of Educational Technology \& Online Learning, 2(2), 102

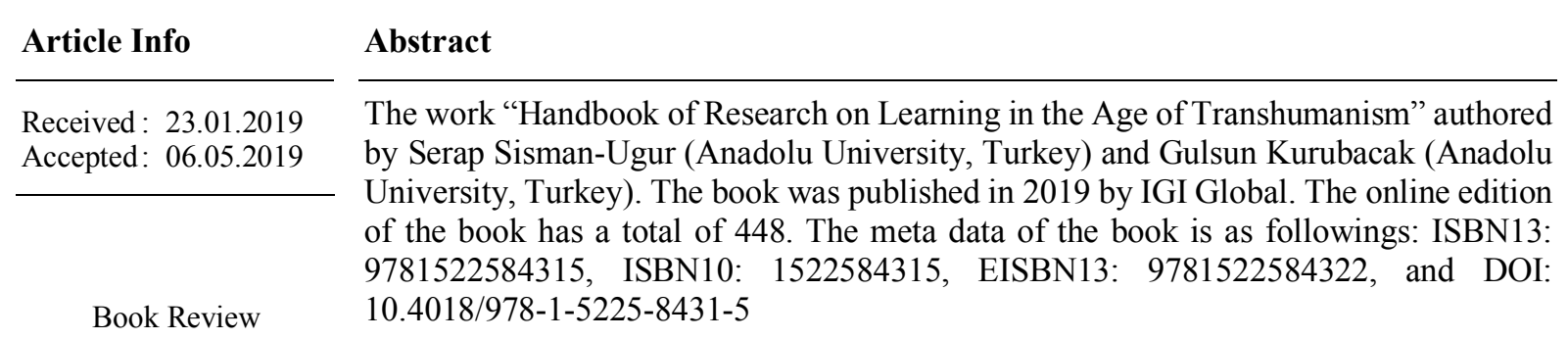

Keywords: Transhumanism, technology, human capabilities, learning, teaching.

\section{INTRODUCTION}

The work "Handbook of Research on Learning in the Age of Transhumanism" authored by Serap Sisman-Ugur (Anadolu University, Turkey) and Gulsun Kurubacak (Anadolu University, Turkey). The book was published in 2019 by IGI Global. The online edition of the book has a total of 448. The meta data of the book is as followings: ISBN13: 9781522584315, ISBN10: 1522584315, EISBN13: 9781522584322, and DOI: 10.4018/978-1-5225-8431-5

\section{REVIEW OF THE BOOK}

This book includes 4 sections and 22 chapters. The first section offers the first chapter of the book named 'Artificial Intelligence to Super Artificial Intelligence, Cyber Culture to Transhumanist Culture: Change of the Age and Human'. 


\section{Section 1: Introduction}

Chapter 1: "Artificial Intelligence to Super Artificial Intelligence, Cyber Culture to Transhumanist Culture: Change of the Age and Human" authored by Ugur and Kurubacak (2019) examines transhumanism and provides insights regarding the future predictions and how, transhumanist implications, will penetrate our lives.

\section{Section 2: Radical Futuristics}

Chapter 2: "Ability to Advance Knowledge and Capacity to Achieve the Impossible" authored by Vita-More (2019) clarifies the accomplishments and changes with the use of technology in the context of encouraging lifelong learning experiences. Transhumanist learning approach offers a social construct in order to prevent upcoming threats and support to get access educational platforms.

Chapter 3: "According to Zoltan Istvan: Transhumanism and Future" authored by Istvan (2019) identifies the future technological trends of improving human body from the perspective of Transhumanism.

Chapter 4: "Automatic IQ Estimation Using Stylometric Methods" authored by Abramov and Yampolskiy defines the Stylometry method and various research fields related to the stylometry and exemplifies a method to estimate an individual's IQ on the basis of the quality of writing and texting features.

\section{Section 3: Technology and Learning}

Chapter 5: "Exocortex as a Learning Technology" authored by Mutlu (2019) studies exocortex as a hypothetical technology which can connect with brain-computer interface to a brain implant or a computational environment which is in the state of a wearable device and investigates the effects of the exocortex technology through the learning processes taking account of the 'learning experiences management' approach. 
Chapter 6: "Transhumanism and Innovative Leadership: A Question of Quality" authored by Ossiannilsson (2019) sheds light on the future trends, innovations, issues and challenges in management and leadership. Being aware of both transhumanism and its effects on leadership and smart learning which learners take the control of their learning process is crucial to take place in a sustainable learning ecosystem.

Chapter 7: "Ethical Issues in Transhumanism" authored by Karaman (2019) introduces ethical issues in transhumanism and tries to find an answer how the ethical aspects of transhumanism can be overcome considering the philosophical approach of ethics.

Chapter 8: "Using Artificial Intelligence in Massive Open Online Courses: A Conceptual View to Wise MOOCs" authored by Güler and Karatop (2019) points out the integration of trending technologies into MOOCs and focuses on intelligent MOOCs and how artificial intelligence can affect the strategical process from the perspective of stakeholders.

Chapter 9: "Transforming the Classroom Experience Through Transhumanism: Education as the Learning" authored by Klinger and Coffman (2019) highlights the pedagogical issues creating new learning experiences which utilize educational technologies in order to promote learners' conceptual competencies and cognitive capabilities.

Chapter 10: "Artificial Intelligence in the Era of Transhumanism Smart Phones" authored by Aksu (2019) examines the points to be emphasized on the process of transferring functions of humans into machines. From the perspective of transhumanists, the improvement of human body will include not only changes of human body but also thinking capacity of machines known as artificial intelligence.

Chapter 11: "The Role, Influence, and Demand of Pedagogies in the Age of Transhumanism: Critical" authored by Misra (2019) identifies the role, impact and demand of pedagogies which has a fundamental role for the transhumanistic societies of the future. Within the scope of transhumanist context, the pedagogies applying important relationship with transhumanism are essential to predict future pedagogies. 
Chapter 12: "Being a Post-Learner with Virtual Worlds" authored by Şahin and Doğan (2019) examines the virtual worlds in transhumanism age. The effects of 3 dimensional virtual worlds can be seen in all aspects of human life as well as on the learning activities. To clarify it virtual worlds have been tried to evaluate under learning context.

Chapter 13: "Innovative Learning Approach in the 21st Century: Personal Learning Environments" authored by Altinpulluk (2019) illustrates the definitions of Personal Learning Environment (PLE), the ways of using PLE, suggestions how to use PLE, and how and which aspects it has advantages and limitations.

Chapter 14: "Artificial Intelligence in Education: Current Insights and Future Perspectives" authored by Goksel and Bozkurt (2019) examines artificial intelligence in terms of education and concludes that (1) adaptive learning, personalization and learning styles, (2) expert systems and intelligent tutoring systems, and (3) AI as a future component of educational processes are three broad themes in this regard.

Chapter 15: "Online and Distance Education in the Era of Rampant Technological Revolution" authored by Ucar (2019) explores how transhumanism and technoculture perspective have an effect on open distance education taking into consideration that transhumanism affects all human beings and even starts to change societies and cultures.

Chapter 16: "From Distance Education to Open and Distance Learning: A Holistic Evaluation of History, Definitions, and Theories" authored by Bozkurt (2019) considers Distance Education (DE) and Open and Distance Learning (ODL), as constantly evolving fields provides a holistic evaluation. The chapter concludes that both DE and ODL become part of the mainstream education. Stressing that mainstreaming should be evaluated with caution, the chapter suggest that there is a need to revisit core values and fundamentals where critical pedagogy would have a pivotal role. Besides, there is no single theory that best explains these interdisciplinary fields, that is DE and ODL, and therefore, there is a need to benefit from different theoretical approaches. Finally, as a result of constant changes, individuals in these fields should keep the definition of both DE and ODL up-to-date to better explain the needs of the global teaching and learning ecosystem. 
Chapter 17: “A Case Study on Pre-Service English Teachers' Perceptions of Self-Efficacy and Integration of Information-Communication Technologies" authored by Istifci (2019) brings pre-service English Language Teachers perceptions to light on ICT integration in language education.

Chapter 18: "Educational Technologies in the Age of Transhumanism" authored by Karadeniz and Ergül (2019) sorts out how transhumanist technologies like virtual reality (VR), augmented reality (AR), and artificial intelligence (AI) can influence the ways of learning and teaching. The last section of the book centers on the how Transhumanism has effects on the fields of business, management, law and health.

\section{Section 4: Business, Management, Law, and Health}

Chapter 19: "Business Management Learning: Research for the Age of Transhumanism" authored by Banger (2019) sheds lights on the significance of preparation and adaptation for the transhumanist business management future considering the speed of technological progress.

Chapter 20: "Transhumanism and Positive Psychological Capital in Organizational Behavior" authored by Urgan (2019) probes the positive psychological capital through transhumanism and investigates how human has an organizational behavior to live a better life psychologically, socially and physiologically in the light of transhumanist perspective.

Chapter 21: "An Evaluation of Transhumanist Bill of Rights from Current and Future Perspective: The Adventure of Technohumanism and Rights" authored by Öngün (2019) focuses on how and to what extend transhumanism will enhance applicable and convenient entities and what need to be done to protect these transhumanist rights.

Chapter 22: "Statistical Resultant Analysis of Psychosomatic Survey on Various Human Personality Indicators: Statistical Survey to Map Stress and Mental Health" authored by Rastogi et. al. (2019) introduces a framework and simulated model which is used some machine learning tools in order to analyze quality of stress and quantitative parameters. Thanks to this model and machine intelligence it is planning to have an expert system to support individual to grow a self as better than human being. 


\section{CONCLUSION AND SUGGESTIONS}

Transhumanism vision a future how technology centric approaches can upgrade human capabilities. In addition to many futuristic opportunities, it is also possible to enhance and enrich learning processes. In this regard, the Handbook of Research on Learning in the Age of Transhumanism (Sisman-Ugur \& Kurubacak, 2019) is a premier reference for those who wants to learn more about transhumanism and learning.

\section{About the Author(s)}

Şeyda Kır

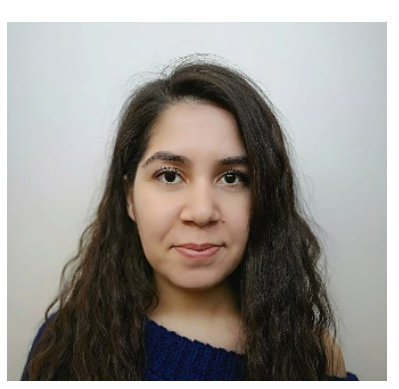

Şeyda Kir, is a graduate student in the Department of Distance Education at Anadolu University. She graduated from Anadolu University, Education Faculty English Language Teaching. Her research interest are lifelong learning, adult education, MOOCs, open and distance learning and skill learning in distance learning environments.

E-mail: seydaakr@gmail.com

ORCID: https://orcid.org/0000-0002-6270-8034

\section{REFERENCES}

Abramov, P. S., \& Yampolskiy, R. V. (2019). Automatic IQ Estimation Using Stylometric Methods. In S. Sisman-Ugur, \& G. Kurubacak (Eds.), Handbook of Research on Learning in the Age of Transhumanism(pp. 32-45). Hershey, PA: IGI Global. doi:10.4018/978-1-5225-8431-5.ch004

Aksu, O. (2019). Artificial Intelligence in the Era of Transhumanism Smart Phones. In S. Sisman-Ugur, \& G. Kurubacak (Eds.), Handbook of Research on Learning in the Age of Transhumanism (pp. 157-170). Hershey, PA: IGI Global. doi:10.4018/978-1-5225$8431-5 . \operatorname{ch} 010$

Altinpulluk, H. (2019). Innovative Learning Approach in the 21st Century: Personal Learning Environments. In S. Sisman-Ugur, \& G. Kurubacak (Eds.), Handbook of Research on Learning in the Age of Transhumanism (pp. 205-223). Hershey, PA: IGI Global. doi:10.4018/978-1-5225-8431-5.ch013

Banger, G. (2019). Business Management Learning: Research for the Age of Transhumanism. In S. Sisman-Ugur, \& G. Kurubacak (Eds.), Handbook of Research on Learning in the 
Age of Transhumanism(pp. 307-327). Hershey, PA: IGI Global. doi:10.4018/978-15225-8431-5.ch019

Bozkurt, A. (2019). From Distance Education to Open and Distance Learning: A Holistic Evaluation of History, Definitions, and Theories. In S. Sisman-Ugur, \& G. Kurubacak (Eds.), Handbook of Research on Learning in the Age of Transhumanism(pp. 252-273). Hershey, PA: IGI Global. doi:10.4018/978-1-5225-8431-5.ch016

Goksel, N., \& Bozkurt, A. (2019). Artificial Intelligence in Education: Current Insights and Future Perspectives. In S. Sisman-Ugur, \& G. Kurubacak (Eds.), Handbook of Research on Learning in the Age of Transhumanism (pp. 224-236). Hershey, PA: IGI Global. doi:10.4018/978-1-5225-8431-5.ch014

Güler, E., \& Karatop, B. (2019). Using Artificial Intelligence in Massive Open Online Courses: A Conceptual View to Wise MOOCs. In S. Sisman-Ugur, \& G. Kurubacak (Eds.), Handbook of Research on Learning in the Age of Transhumanism(pp. 116-133). Hershey, PA: IGI Global. doi:10.4018/978-1-5225-8431-5.ch008

Istifci, I. (2019). A Case Study on Pre-Service English Teachers' Perceptions of Self-Efficacy and Integration of Information-Communication Technologies. In S. Sisman-Ugur, \& G. Kurubacak (Eds.), Handbook of Research on Learning in the Age of Transhumanism (pp. 274-290). Hershey, PA: IGI Global. doi:10.4018/978-1-52258431-5.ch017

Istvan, Z. (2019). According to Zoltan Istvan: Transhumanism and Future. In S. Sisman-Ugur, \& G. Kurubacak (Eds.), Handbook of Research on Learning in the Age of Transhumanism (pp. 28-31). Hershey, PA: IGI Global. doi:10.4018/978-1-5225-84315.ch003

Karadeniz, Ş., \& Ergül, I. B. (2019). Educational Technologies in the Age of Transhumanism. In S. Sisman-Ugur, \& G. Kurubacak (Eds.), Handbook of Research on Learning in the Age of Transhumanism(pp. 291-305). Hershey, PA: IGI Global. doi:10.4018/978-15225-8431-5.ch018

Karaman, F. (2019). Ethical Issues in Transhumanism. In S. Sisman-Ugur, \& G. Kurubacak (Eds.), Handbook of Research on Learning in the Age of Transhumanism(pp. 98-115). Hershey, PA: IGI Global. doi:10.4018/978-1-5225-8431-5.ch007

Klinger, M. B., \& Coffman, T. L. (2019). Transforming the Classroom Experience Through Transhumanism: Education as the Learning Organization. In S. Sisman-Ugur, \& G. Kurubacak (Eds.), Handbook of Research on Learning in the Age of 
Transhumanism (pp. 134-156). Hershey, PA: IGI Global. doi:10.4018/978-1-52258431-5.ch009

Misra, P. K. (2019). The Role, Influence, and Demand of Pedagogies in the Age of Transhumanism: Critical Reflections. In S. Sisman-Ugur, \& G. Kurubacak (Eds.), Handbook of Research on Learning in the Age of Transhumanism (pp. 171-184). Hershey, PA: IGI Global. doi:10.4018/978-1-5225-8431-5.ch011

Mutlu, M. E. (2019). Exocortex as a Learning Technology. In S. Sisman-Ugur, \& G. Kurubacak (Eds.), Handbook of Research on Learning in the Age of Transhumanism (pp. 47-77). Hershey, PA: IGI Global. doi:10.4018/978-1-5225-8431-5.ch005

Ossiannilsson, E. S. (2019). Transhumanism and Innovative Leadership: A Question of Quality. In S. Sisman-Ugur, \& G. Kurubacak (Eds.), Handbook of Research on Learning in the Age of Transhumanism (pp. 78-97). Hershey, PA: IGI Global. doi:10.4018/978-1-52258431-5.ch006

Öngün, E. (2019). An Evaluation of Transhumanist Bill of Rights From Current and Future Perspective: The Adventure of Technohumanism and Rights. In S. Sisman-Ugur, \& G. Kurubacak (Eds.), Handbook of Research on Learning in the Age of Transhumanism (pp. 346-362). Hershey, PA: IGI Global. doi:10.4018/978-1-5225$8431-5 . \operatorname{ch} 021$

Rastogi, R., Chaturvedi, D. K., Sharma, P., Yadav, V., Chauhan, S., Gulati, M., Gupta, M., \& Singhal, P. (2019). Statistical Resultant Analysis of Psychosomatic Survey on Various Human Personality Indicators: Statistical Survey to Map Stress and Mental Health. In S. Sisman-Ugur, \& G. Kurubacak (Eds.), Handbook of Research on Learning in the Age of Transhumanism(pp. 363-383). Hershey, PA: IGI Global. doi:10.4018/978-1-52258431-5.ch022

Şahin, F., \& Doğan, E. (2019). Being a Post-Learner With Virtual Worlds. In S. Sisman-Ugur, \& G. Kurubacak (Eds.), Handbook of Research on Learning in the Age of Transhumanism (pp. 185-204). Hershey, PA: IGI Global. doi:10.4018/978-1-52258431-5.ch012

Ucar, H. (2019). Online and Distance Education in the Era of Rampant Technological Revolution. In S. Sisman-Ugur, \& G. Kurubacak (Eds.), Handbook of Research on Learning in the Age of Transhumanism (pp. 237-251). Hershey, PA: IGI Global. doi:10.4018/978-1-5225-8431-5.ch015 
Uğur, S., \& Kurubacak, G. (2019). Artificial Intelligence to Super Artificial Intelligence, Cyber Culture to Transhumanist Culture: Change of the Age and Human. In S. Sisman-Ugur, \& G. Kurubacak (Eds.), Handbook of Research on Learning in the Age of Transhumanism (pp. 1-16). Hershey, PA: IGI Global. doi:10.4018/978-1-5225-84315.ch001

Sisman-Ugur, S., \& Kurubacak, G. (2019). Handbook of Research on Learning in the Age of Transhumanism (pp. 1-448). Hershey, PA: IGI Global. doi:10.4018/978-1-5225-84315

Urgan, S. (2019). Transhumanism and Positive Psychological Capital in Organizational Behavior. In S. Sisman-Ugur, \& G. Kurubacak (Eds.), Handbook of Research on Learning in the Age of Transhumanism (pp. 328-345). Hershey, PA: IGI Global. doi:10.4018/978-1-5225-8431-5.ch020

Vita-More, N. (2019). Ability to Advance Knowledge and Capacity to Achieve the Impossible. In S. Sisman-Ugur, \& G. Kurubacak (Eds.), Handbook of Research on Learning in the Age of Transhumanism(pp. 18-27). Hershey, PA: IGI Global. doi:10.4018/978-1-52258431-5.ch002 